\title{
Beyond Typologies of Global Value Chain Governance: the Accumulation of Technological Capabilities
}

\author{
Zhenming Sun (Corresponding author) \\ The O\&M Project Management, Sinoma SCC Project \\ Na Bi WU PO box 67105, AL-HASSA 31928, Kingdom of Saudi Arabia \\ Tel: 96-6-532-076-880 E-mail: wjszm@163.com \\ Guanghui Zhang \\ Guanghua School of Business Management \\ Peking University \\ 176 Zhong Guan Cun Street, Beijing 100086, China \\ Tel: 96-6-532-076-881Ｅ-mail: zhangguanghui@gsm.pku.edu.cn
}

\begin{abstract}
Global value chains (GVC) offer opportunities and challenges for business developing in low income economies. The existing literature on GVC mainly focuses on two niches: governance and upgrading. The global buyers play as 'lead firm' in GVC context. However, the issues of upgrading activities at firm-level remain largely uncovered by the GVC literature. From the perspective of the literature on technological capabilities, this paper presents a framework to examine the levels of upgrading activities of producers in low income economies in the GVC quasi-governance structure.
\end{abstract}

Keywords: Global value chains, Governance, Upgrading, Technological capabilities

\section{Introduction}

Global value chains offer opportunities and challenges for business development in low-income economies. On the one hand, they can bring access to overseas markets, particularly developed world's market. On the other hand, entry to the value chain may be dependent on supplying low value products as low cost and a willingness to maintain at this level of activity. Consequently, a fundamental issue is that do GVC supports business growth in a low-income economy.

To date, the GVC research mainly focuses on two niches: governance and upgrading. It has offers a framework that is relevant on the analysis as well as a depth understanding of how low-income economies fashion development strategies to climb up a higher value niches in the global economy. Nevertheless, the GVC approach is still an embryonic theory of development. It is good to mention some further efforts will have to be done. The purpose of this paper is to demonstrate how accumulation of technological capabilities of local producers with the assistance of global buyers in GVC context.

This paper is organized as follows. In the next section we will present a critical review on governance and upgrading in the GVC literature. Section 3 we outline a framework of analysis by adopting technological capabilities literature into GVC context. Section 4 summarizes and concludes.

\section{Previous GVC literature: governance and upgrading}

The definition of 'governance' is firstly introduced by Gereffi (1994), defined as "authority and power relationship that determine how financial, material, and human resources are allocated and follow within a chain" (p.97). Governance is now central in GVC literature. Recent efforts on GVC governance have paid much attention rather than original contribution on non-hierarchical governance forms. A set of strategic parameters can be highlighted as characterizing governance types: 'what' or 'how' a product/service should be produced as well as 'when', 'how much' and even 'at the price'. Drawing upon these parameters, Humphrey and Schmitz (2000) distinguish three possible types of governance: network, quasi-hierarchy and hierarchy. In the context of 'network' governance, there are relationships that encourage enterprises with complementary which jointly establish the key parameters. Within this governance, the term is frequently used to denote some form of co-operation between 'equal'. Regarding other two types of governances, 
there are relationships characterized by a remark asymmetry of competence and power distribution between lead firms and subordinate firms in the chain. A quasi-hierarchy governance can be explained that the lead firms tend to specify what is to be produced, how it is to produced and how the firm performance is to be monitored. They argue this type of governance is common to exist in developing countries. In most of cases, the global buyers act as lead firms. More importantly, Humphrey and Schmitz (2000) also suggest that global buyers tend to disclose their core competencies to local suppliers.

The most recent valuable governance models is published in an article entitled, 'the governance of global value chain' in the journal Review of international political economy (Gereffi, Humphrey, and Sturgeon, 2005). They go deeper into the analysis of factors affecting alternative types (see Figure 1). They point out four kinks of transactional linkages between lead firms and subordinate firms: market, modular, relational, captive and hierarchy. They also identify the idea that three key determinates of value chains relationships: the complexity of information and knowledge transfer required to sustain a particular transaction, especially with respect to product and process specifications; the extent to which this information knowledge can be codified and, therefore, transmitted efficiently and without transaction-specific investment between the parties to the transaction; the capabilities of actual and potential suppliers in relation to the requirements of the transaction.

Undoubtedly, the contribution to GVC governance can be presented essential insights from a wide range of perspectives. To some extent, coordination in the context of global value chains can be occur a variety of models; the advantage of lead firm within global value chains is based on their strong marketing power and their positioning in chain niches; GVC governance indicate the capability of one in the separate segments of the chains to affect or determine the survival of other businesses along the chains, and; Initially, the structures of GVC structure emerge in answer to two key demands. That is, an increasing number of firms are embedded into specifying the products that their suppliers need to produce, the more these firms are willing to concentrate on constructing on GVC governance structures to cooperate with their own suppliers. Besides, in the case of the emergence of risks as a result of the failures of their suppliers, they are more likely to directly intervene to cooperate or inspect the supplying chain.

The link between enterprise upgrading and GVC governance has also been made more explicit. That is, upgrading is also a key concept for value chain analysis. Global value chain discussion of upgrading has demonstrated two distinct directions (Gibbon, 2003):

- A wider vocabulary of upgrading possibilities has been produced, and it has made some efforts to develop analytical links between types of value chain governance structure and the prevalence of specific upgrading possibilities.

- From a chain-by-chain perspective, insertion into a value chain appears to offer higher and more stable returns to actors below the level of leading agent, and decides how those agents achieved there.

The first of these directions is taken by Humphrey and Schmitz (2002), who make a distinction between three types of upgrading, including process-, product- and functional upgrading:

- Process upgrading can be defined as "transforming inputs to outputs more efficiently by re-organising the production system or introducing superior technology".

- Product upgrading implies the "making of a product that is of better quality, more sophisticated or simply carries a better price".

- Functional upgrading can be described as "repositioning a given firm at a higher level of the value chain".

- Gereffi (1999) introduces two further types of upgrading called inter-sector upgrading and the upgrading of marketing linkages (which is less used).

- Inter-sector upgrading refers to " firms that apply the competence acquired in a particular function of a chain (e.g. competence in producing particular inputs, or in export marketing in a new sector";

- $\quad$ Upgrading of marketing linkages refers to a shift to higher value added chains and lead firms.

The explanation of upgrading activities have been frequently adopted by the literature on competitiveness (Porter 1990; Kaplinsky and Readman, 2001). A large number of recent researches are working on the identification of the differences between the "high" and "low road" to competitiveness with the ability of businesses to upgrade themselves (Pietrobelli and Rabellotti, 2004; Schmitz, 2006). Such researches share the common sense of urgency seeking for sustainable upgrading of industrial clusters in the developing countries.

In sum, the previous literature mainly focuses on two niches: governance and upgrading. The GVC literature on these two niches has offered a framework that is not only relevant on the analysis of firms, but also to an understanding of how countries fashion development strategies to attempt to move themselves into relatively high value, sustainable niches in the global economy. However, a number of issues still need to address (Gerffi, 2001). Many researchers have 
been working on building up a comprehensive GVC theory. Among them, Morrison et al (2006) introducing a framework with bringing explicitly the technological capabilities framework into the GVC approach. In this framework, they recognize that there is little or nothing about the vertical dimension of upgrading activities in GVC literature. Unfortunately, a detailed discussion on this issue is absent. The purpose of this paper is to fill this gap.

\section{A conceptual framework for vertical dimensions of upgrading activities}

According to the existing literature, there is a common sense that with the supporting of global buyers, the upgrading of suppliers commences from process and product, then moves up to functional upgrading and end of all, to achieve competitiveness. With the reference to current approach, Humphrey and Schmitz (2000) discuss the prospect of upgrading related to the mode of GVC governance. They suggest that insertion into a quasi-hierarchical chain offers very favourable conditions for suppliers to process and upgrading, but hinder functional upgrading. In this case, when authors observe the upgrading activities, they tend to invariably link to the outcome of upgrading activities to competitiveness. However, draw from the literature of Humphrey and Schmitz (2000) and Bazan and Navas-Aleman, (2004), it is almost impossible for these buyers form domestic and other Third World can compete with the developed country's buyers. That is, it is hard to image that local suppliers can insert into a higher niche in GVC context by this upgrading path. Morrison, Pietrobelli and Rabellotti (2006) argue that there is a strong temptation of mixing causes and efforts in many empirical studies. They also claim that the classification of this upgrading is weak to translate into firm-level study. According to the literature on GVC, there are several types of GVC governance, encompassing market hierarchy (Gereffi et al, 2005). In line with the empirical studies for low income economies, the quasi-hierarchy governance is central. In this governance structure, it can be characterized by the significant dependence of small suppliers on large global buyers for advanced production methods, the design of production and marketing. This type of GVC governance is most common in low income economies. Although recent empirical studies explore that the local producers achieve product and process upgrading but not functional upgrading, (Bazan and Navas-Alemán, 2003), the global buyers still play as the lead firm. That is, the global buyers play a significant role for producers in low income economies to insert into global economies. For this reason, the framework of evaluation of vertical dimensions of upgrading activities should focus on the context of quasi hierarchy governance structure. To some extent, the framework aims to explore the issues, for example, how global buyers assist local producers from low income economies to climb up into higher value niches?

In the context of GVC, technological capability refers to the capacity of local supplier with the support of global buyers to generate and manage technological change. In this case, the technological change capability can explain: a body of knowledge and experience that is probably significantly distinguishing from what is needed to run existing systems. Innovative local suppliers are able to improve given technologies. Capability accumulation involves the extent to which a local supplier commits to absorbing new technological capabilities based on learning from its purchasing agent(s), creating new skills, or revitalizing in new situations (Luo, 2002).

Due to the process of incremental learning as well as evolutionary process of developing locally-refined skills and routines, technological capability is a cumulative process. Technological change can be induced through both routine production and the need for critical revision (Cantwell, 2001). Indeed, the original contribution of this paper is to reconsider the GVC literature to investigate the accumulation of technological capabilities occur in GVC context. This effort explicitly hinges on the literature on technological capabilities.

The taxonomy of technological capabilities for the suppliers from low income economies in GVC contexts on the analytical framework by Bell \& Pavitt (1995) and Lall (1992). The taxonomy is based on the evidence of the characteristics on the accumulation processes of technological capabilities in developing countries' suppliers in global value chains. The taxonomy of technological capabilities can be identified into two basic levels(Li, 2006).

Basic routine capability is defined as the capability to produce goods at given levels of efficiency and given input requirement. It may be described as technology-using skills and knowledge (Bell and Albu, 1999).

Innovation technological capability is the capability to change or improve products and processes. It may be described as change-generating capability or technology-changing skill (Bell and Albu, 1999).

To some extent, there are four levels of technological capabilities: the primary level (basic routine capability), and three innovative capability levels (Table 1)

Following the Lall (2001), there are three capabilities which apply to local suppliers in GVC context: (i) investment capabilities refer to the skills required before and during the investment; (ii)production capabilities include the generation and management of technical change in processes, products, and production organization; and (iii), Linkage capabilities are required due to high transaction costs in an inefficient marketing situation where the setting up of extra marking linkages usually corresponds to an efficient strategy.

Table 2 presents the taxonomy of technological capabilities for the local producers in low income economies in GVC context. It illustrates each stage in the accumulation of local producers under the support of global buyers, and lists the 
activities most characteristic of each level.

\section{Conclusions and implications for further research}

Nevertheless, the GVC approach accentuates the natures of the relationships among various factors involved in the value chains, and their implications for business growth. However, recent studies have not fully clarified how global chains foster upgrading activities in low income economies at a firm-level focus. To some extent, due to the fact that the theory of GVC governance and upgrading originally stem from the case studies, they tend to fail to address the issues on firm level. For example, the existing literature will fail to answer the question and the like as follows:

- Why do firms in the same industry and cluster demonstrate starkly different approaches to brining their products to global markets; or

- $\quad$ Under the same governance structure, why some firms can upgrade into global value chains; some are not able to do that? What factors beyond the governance context determine this?

Therefore, this does seem to be a very fruitful area for future research. We stress two significant points here.

First, firm level surveys or questionnaires can be produced to explore the phenomenon how local producers improve their technological capability in quasi-hierarch governance structure.

Secondly, beyond the GVC governance and upgrading, a wide range of research agenda are largely under research. For example, existing literature tends of focus on a buyer or supplier perspective without considering the transaction between the two parties holistically.

\section{References}

Bazan, L. and L. Navas-Alemán. (2003). Upgrading in Global and National Value Chains: recent challenges and opportunities for the Sinos Valley footwear cluster, Brazil. Eadi's Workingshop "cluster and global value chains in the North and Third World." Novara.

Bell, M. and M. Albu. (1999).Knowledge Systems and technological dynamism in industrial clusters in developing countries. World developmen, 27(9), 1715-1734.

Gerffi, G. (2001). Shifting governance structures in global commodity chains, with special reference to the Internet. American behavioral scientist, 4(10), 616-1637.

Gibbon, P. (2003). Commodities, Donors, Value Chains Analysis and Upgrading. Danish institue for international studies, Denmark.

Kaplinsky, R. and J. Readman. (2001). How can SME producers serve global markets and sustain income growth?

Li, H. P. (2006). The accumulation of technological capability within international joint ventures in China. Graduate school-netwark Rugers. Netwark, The State University of New Jersey.

Pietrobelli, C. and R. Rabellotti. (2004). Competitiveness and Upgrading in Clusters and Value Chains. An instituional approach to competitveness-the critical role of instituions at the national and regional level. Pretoria, South Africa.

Porter, M. E. (1990). The competitive advantage of nations. London : New York, Macmillan; Free Press.

Schmitz, H. (2006). Learning and earning in global garment and footwear chains. The European journal of develeopment research, 18(4), 546-571.

Table 1. Four level of technological capabilities of developing countries'suppliers in GVC context

\begin{tabular}{|c|c|c|}
\hline Level & Sub-levels & Description \\
\hline Primary & Basic routine capability & $\begin{array}{r}\text { With the ability to produce goods at given levels of efficiency } \\
\text { and given input requirement }\end{array}$ \\
\hline Innovative & $\begin{array}{c}\text { Basic innovative } \\
\text { capability }\end{array}$ & $\begin{array}{c}\text { With the support of global buyers, the local suppliers have } \\
\text { the ability to make incremental changes of process to } \\
\text { improve quality }\end{array}$ \\
\cline { 2 - 3 } & $\begin{array}{c}\text { Intermediate innovative } \\
\text { capability }\end{array}$ & $\begin{array}{c}\text { With the support of global buyers, the local suppliers have } \\
\text { full production skill and the capability for process innovation } \\
\text { and product design }\end{array}$ \\
\cline { 2 - 3 } & $\begin{array}{c}\text { Advanced innovative } \\
\text { capability }\end{array}$ & $\begin{array}{c}\text { With the support of global buyers, the local suppliers conduct } \\
\text { their won R\&D for products and processes, and are able to } \\
\text { develop product innovation capabilities on its own }\end{array}$ \\
\hline
\end{tabular}

Source: based on Bell \& Pavitt (1995). 
Table 2. The accumulation of technological capabilities of suppliers in low income economies in the GVC context

\begin{tabular}{|c|c|c|c|c|c|}
\hline \multirow{2}{*}{$\begin{array}{c}\text { Capability } \\
\text { Level }\end{array}$} & \multicolumn{2}{|c|}{ Investment capabilities } & \multicolumn{2}{|c|}{ Production capabilities } & \multirow{2}{*}{$\begin{array}{c}\text { Supporting } \\
\text { capabilities } \\
\text { Developing } \\
\text { linkages }\end{array}$} \\
\hline & $\begin{array}{l}\text { Decision making } \\
\text { control }\end{array}$ & $\begin{array}{c}\text { Project } \\
\text { preparation and } \\
\text { implementation }\end{array}$ & $\begin{array}{l}\text { Organization of } \\
\text { process and } \\
\text { production }\end{array}$ & Product centred & \\
\hline $\begin{array}{c}\text { Basic operative } \\
\text { capabilities }\end{array}$ & $\begin{array}{l}\text { Engaging primary } \\
\text { contractor and } \\
\text { payment estimation }\end{array}$ & $\begin{array}{l}\text { Preparation of } \\
\text { initial project } \\
\text { outline; } \\
\text { Construction of } \\
\text { basic civil works }\end{array}$ & $\begin{array}{c}\text { Routine } \\
\text { operation of } \\
\text { and basic } \\
\text { maintenance; } \\
\text { Efficiency } \\
\text { improvement } \\
\text { from experience } \\
\text { in existing tasks }\end{array}$ & $\begin{array}{l}\text { Replication of } \\
\text { product } \\
\text { specification } \\
\text { and designs }\end{array}$ & $\begin{array}{l}\text { Procurement } \\
\text { of available } \\
\text { inputs from } \\
\text { existing } \\
\text { suppliers; Sale } \\
\text { of given } \\
\text { products to } \\
\text { existing and } \\
\text { new customers }\end{array}$ \\
\hline $\begin{array}{c}\text { Basic } \\
\text { innovative } \\
\text { capabilities }\end{array}$ & $\begin{array}{l}\text { Active monitoring } \\
\text { and control of } \\
\text { feasibility study, } \\
\text { Technology } \\
\text { choice/sourcing and } \\
\text { project scheduling }\end{array}$ & $\begin{array}{c}\text { Project } \\
\text { feasibility study, } \\
\text { Standard } \\
\text { equipment } \\
\text { procurement and } \\
\text { simple ancillaries } \\
\text { engineering }\end{array}$ & $\begin{array}{l}\text { Improving } \\
\text { layout, } \\
\text { scheduling; } \\
\text { Maintenance } \\
\text { and minor } \\
\text { process } \\
\text { adaptation }\end{array}$ & $\begin{array}{l}\text { Minor } \\
\text { adaptations to } \\
\text { market needs, } \\
\text { and; } \\
\text { Incremental } \\
\text { improvement in } \\
\text { product quality }\end{array}$ & $\begin{array}{c}\text { Searching and } \\
\text { absorbing new } \\
\text { information } \\
\text { for local } \\
\text { producers }\end{array}$ \\
\hline $\begin{array}{l}\text { Intermediate } \\
\text { innovative } \\
\text { capabilities }\end{array}$ & $\begin{array}{l}\text { Search, evaluation } \\
\text { and selection of } \\
\text { technology }\end{array}$ & $\begin{array}{c}\text { Detailed } \\
\text { engineering; } \\
\text { Project } \\
\text { scheduling and } \\
\text { management; } \\
\text { Commissioning }\end{array}$ & $\begin{array}{c}\text { Process } \\
\text { improvement, } \\
\text { licensing new } \\
\text { technology; } \\
\text { Introducing, } \\
\text { production } \\
\text { organizational } \\
\text { changes }\end{array}$ & $\begin{array}{l}\text { Licensing new } \\
\text { product } \\
\text { technology and/ } \\
\text { or Reverse } \\
\text { engineering } \\
\text { incremental } \\
\text { new product } \\
\text { designs }\end{array}$ & $\begin{array}{l}\text { Technology } \\
\text { transfer to } \\
\text { local suppliers } \\
\text { to increase } \\
\text { efficiency, } \\
\text { quality for } \\
\text { local supply }\end{array}$ \\
\hline $\begin{array}{l}\text { Advanced } \\
\text { Innovative } \\
\text { capabilities }\end{array}$ & $\begin{array}{l}\text { Developing new } \\
\text { production systems } \\
\text { and components; } \\
\text { Product innovation } \\
\text { and related R\&D }\end{array}$ & $\begin{array}{l}\text { Basic process } \\
\text { design related } \\
\text { R\&D }\end{array}$ & $\begin{array}{l}\text { Innovation in } \\
\text { processes and } \\
\text { related } R \& D\end{array}$ & $\begin{array}{l}\text { Design of basic } \\
\text { characteristics } \\
\text { for new } \\
\text { products; } \\
\text { Product } \\
\text { innovation and } \\
\text { related R\&D }\end{array}$ & $\begin{array}{c}\text { Collaboration } \\
\text { in } \\
\text { technological } \\
\text { development } \\
\text { with suppliers }\end{array}$ \\
\hline
\end{tabular}

Source: Based on Bell \& Pavitt, (1995); Lall, (2001).

\begin{tabular}{|c|c|c|c|}
\hline Variable & $\begin{array}{c}\text { Complexity of } \\
\text { transactions }\end{array}$ & $\begin{array}{c}\text { Ability to codify } \\
\text { transactions }\end{array}$ & $\begin{array}{c}\text { Capabilities in } \\
\text { supply-base }\end{array}$ \\
\hline Governance & & \\
\hline Modular & & Low & High \\
\hline Relational & High & Low \\
\hline Captive & High \\
\hline Hierarchy & Low \\
\hline
\end{tabular}

Figure 1. Dynamics in global value chains governance

Source: Gereffi, Humphrey \& Sturgeon, (2005). 